\title{
Nytt Norsk pasientregister gir nye forskningsmuligheter
}

\author{
Inger Johanne Bakken, Monica Grøtte Estenstad, Stein Olav Gystad, Julia Németh \\ og Unn Elisabeth Huse \\ Helsedirektoratet, avd. Norsk pasientregister, Pb 6173 Sluppen, 7435 Trondheim \\ Korrespondanse: inger.johannebakken@helsedir.no
}

\begin{abstract}
SAMMENDRAG
Epidemiologisk forskning, eller forskning som kan gi ny viten om sykdommers årsaker, utbredelse og forløp, er et av formålene for Norsk pasientregister. Norsk pasientregister inneholder informasjon om aktivitet i spesialisthelsetjenesten og omfatter data fra somatiske sykehus, psykisk helsevern for barn og unge, psykisk helsevern for voksne, tverrfaglig spesialisert rusbehandling, og privatpraktiserende avtalespesialister. Norsk pasientregister fikk hjemmel til innhenting av direkte personidentifiserbare data (fødselsnummer) gjennom en endring i helseregisterloven vedtatt av Stortinget i februar 2007. Data i Norsk pasientregister omfatter derfor nå også fødselsnummer i kryptert form. Det krypterte fødselsnummeret kan dekrypteres ved behov, for eksempel for sammenstilling med andre registerdata, data fra befolkningsundersøkelser eller kliniske data. I denne artikkelen beskriver vi Norsk pasientregister som personidentifiserbart register, informerer om nye muligheter og viser eksempler på ny statistikk fra registeret. Vi beskriver også hvordan forskningsmiljøene kan få tilgang til data fra registeret.
\end{abstract}

\section{INNLEDNING}

Norsk pasientregister (NPR) inneholder informasjon om ventetider og aktivitet for spesialisthelsetjenesten i Norge. Formålet med registeret er regulert av Forskrift om innsamling og behandling av helseopplysninger i Norsk pasientregister (Norsk pasientregisterforskriften), jf. forskriftens $\S 1-2$ (1):

- NPR skal danne grunnlag for administrasjon, styring og kvalitetssikring av spesialisthelsetjenester, herunder den aktivitetsbaserte finansieringsordningen.

- NPR skal bidra til medisinsk og helsefaglig forskning som kan gi viten om helsetjenester, behandlingseffekter, diagnoser, og sykdommens årsaker, utbredelse og forløp og forebyggende tiltak.

- NPR skal danne grunnlag for etablering og kvalitetssikring av sykdoms- og kvalitetsregistre.

- NPR skal bidra til kunnskap som gir grunnlag for forebygging av ulykker og skader.

Helsedirektoratet skal ha en aktiv informasjonsstrategi og -plan rettet mot brukergruppene, herunder forskere innen medisinsk forskning, helsetjenesteforskning og samfunnsforskning, jf. Norsk pasientregisterforskriften, $\S 3-11$.

I 2004 publiserte Norsk epidemiologi et temanummer om registerforskning hvor det også inngikk en artikkel om forskningsmuligheter med data fra Norsk pasientregister (2). Gjennom den foreliggende artikkelen ønsker vi å orientere om endringer knyttet til innhold, regulering og organisering, og om hva endringene betyr for forskere som ønsker å bruke data fra Norsk pasientregister.

Da det har vært bare mindre endringer når det gjelder variable relatert til medisinske opplysninger, tar vi $\mathrm{i}$ det følgende først og frem for oss den viktigste endringen for Norsk pasientregister som datakilde i epidemiologisk forskning, nemlig etablering av personidentifiserbart register. $\mathrm{Vi}$ henviser ellers til våre nettsider (http://www.helsedirektoratet.no/norsk pasientregister) for beskrivelse av variable, og til nettsidene til Kompetansesenter for IT i Helsevesenet (www.kith.no) for informasjon om aktuelle kodeverk.

\section{ORgaNiSERING}

Norsk pasientregister er organisert som en avdeling $i$ Helsedirektoratet og er lokalisert til Trondheim. Hvert av registerområdene somatiske sykehus, psykisk helsevern for barn og unge, psykisk helsevern for voksne, tverrfaglig spesialisert rusbehandling, ventelister og privatpraktiserende avtalespesialister følges opp av egne team som bl.a. ivaretar kontakt med rapporteringsenhetene og tilrettelegger data og statistikk. Datautleveringer er organisert $i$ et eget team. I tillegg kommer ulike stabsfunksjoner, slik at det totalt er omtrent 40 stillinger knyttet til avdelingen.

\section{NORSK PASIENTREGISTER SOM PERSON- IDENTIFISERBART REGISTER}

Norsk pasientregister ble opprettet som et avidentifisert register med konsesjon fra Datatilsynet i 1997 og ble driftet av forskningsstiftelsen SINTEF på oppdrag fra Helse- og omsorgsdepartementet frem til avdelingen ble virksomhetsoverdratt til Helsedirektoratet $\mathrm{i}$ 2007. Gjennom en endring i helseregisterloven vedtatt av Stortinget i februar 2007 fikk Norsk pasientregister hjemmel til å samle inn personidentifiserbare data uten samtykke, jf. helseregisterloven $\S 8,3$. ledd (2). Innsamlingen startet med virkning fra 1. januar 2008. Driften av registeret reguleres nærmere gjennom Norsk pasientregisterforskriften som trådte i kraft 15 . april 2009 (1). Med dette ble også Helsedirektoratet databehandlingsansvarlig for registeret. 
$\square$ Somatikk $₫$ BUP $\square$ VOP $\square T S B$

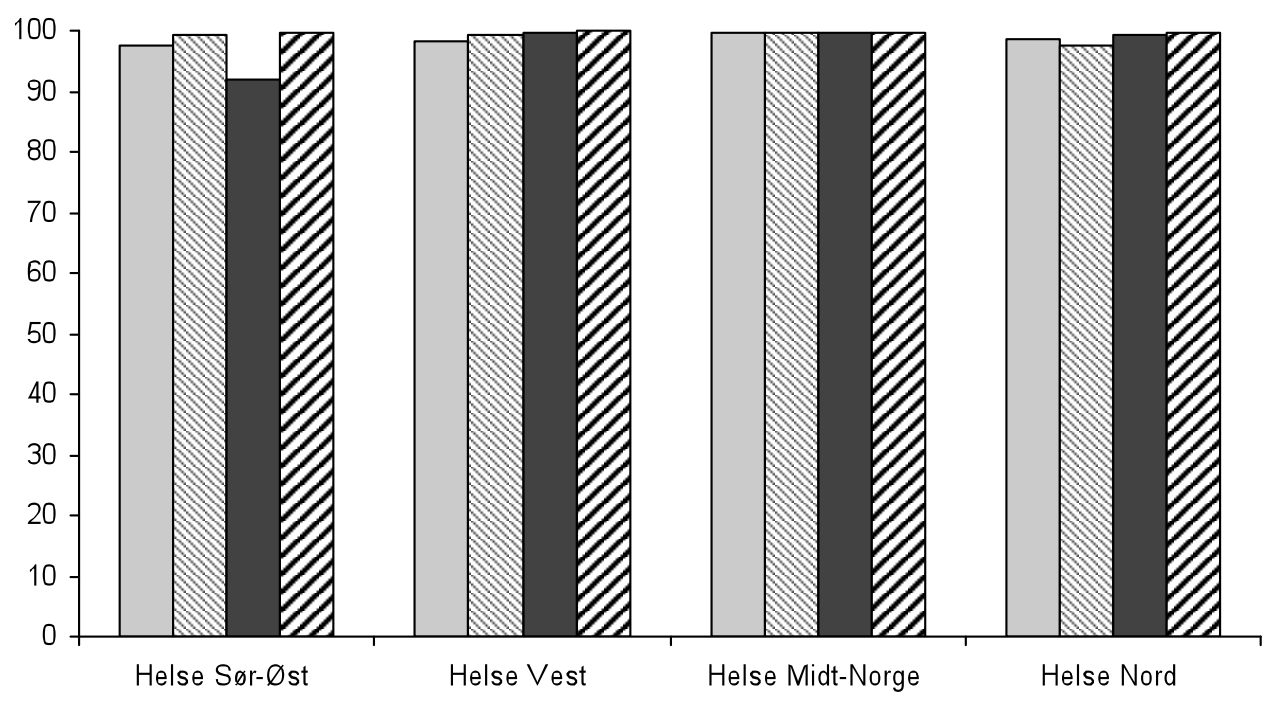

Figur 1. Andel opphold med gyldig fødselsnummer 2009 registrert i Norsk pasientregister: somatiske sykehus, psykisk helsevern for barn og unge (BUP), psykisk helsevern for voksne (VOP), tverrfaglig spesialisert behandling for rusmiddelbrukere (TSB).

Endringen i helseregisterloven innebar at Norsk pasientregister fikk anledning til å samle inn direkte personidentifiserbare opplysninger. Fra 2008 har hver rapporteringsenhet $\mathrm{i}$ tillegg til en melding som inneholder informasjon om aktiviteten ved enheten også sendt inn en såkalt identmelding. Identmeldingen inneholder fødselsnumre for pasienter som har vært henvist til eller behandlet ved enheten, samt en nøkkel for kobling til venteliste- og aktivitetsdata. Når identmeldingen ankommer registeret, blir fødselsnummer kryptert og det krypterte fødselsnummeret blir deretter lagt til aktivitetsdataene (intern kryptering). Fødselsnumre kan dekrypteres ved behov, for eksempel for sammenstilling med andre registre. Denne løsningen medfører at de aller fleste medarbeidere i Norsk pasientregister sjelden eller aldri har tilgang til fødselsnumre for pasienter.

Rapporteringen av fødselsnummer i 2009 var god i alle helseforetak (Figur 1). Ved private sykehus er andelen opphold med gyldig fødselsnummer noe lavere $(83 \%)$.

Data fra privatpraktiserende avtalespesialister omfatter foreløpig ikke fødselsnummer, men arbeidet med første innsamling av identmelding pågår nå. Denne innsamlingen omfatter data for pasienter registrert fra 2008 og fremover.

Tidligere har Norsk pasientregister kun inneholdt et pasientnummer som var unikt for hvert individ innenfor én enhet i ett kalenderår. Dette innebar at det ved behandlingsforløp med hyppig kontakt med flere institusjoner for den enkelte pasient ikke lot seg gjøre å estimere forekomst av tilstanden. Det var heller ikke mulig å undersøke utfall av behandling, verken gjennom pasientforløp med data fra Norsk pasientregisteret eller ved sammenstilling med andre datakilder. Behovet for mer kunnskap om utbredelse og behandling av sykdom ble brukt som argument i diskusjonen omkring Norsk pasientregister som personidentifiserbart register, med hjertesykdom som ofte brukt eksempel (4). Det kan også nevnes at Folkehelseinstituttet i 2005 utga et hefte om behov for personidentifiserbare helseregistre med eksempler på registerforskning fra de nordiske landene (5).

På grunn av muligheten for bakveisidentifisering, må data fra Norsk pasientregister uavhengig av tilgang til fødselsnummer, både før og etter etablering av personidentifiserbart register, betraktes som personidentifiserbare, jf. helseregisterloven $\S 2 \mathrm{nr}$. 3. Denne problemstillingen er det viktig å være klar over for de som ønsker tilgang til data fra registret. Vi vil derfor beskrive dette nærmere i denne artikkelen.

\section{Personvern PÅ ALVOR}

Helseregisterloven $\S 1$ stadfester at helseopplysninger skal behandles i samsvar med grunnleggende personvernhensyn. Helseregisterlovens hovedregel er videre at registrering og behandling av helseopplysninger skal være basert på samtykke fra den registrerte, jf. helseregisterloven $\S 5,3$. ledd. Norsk pasientregister er et sentralt, personidentifiserbart helseregister uten samtykkekrav med hjemmel i helseregisterlovens $\S 8,3$. ledd. Ved etableringen av det personidentifiserbare registeret ble det foretatt en avveining mellom formålet som registeret skal ivareta og personvernulempene, jf. Ot.prp nr. 49 (2005-2006) (6). Behandling av helseopplysninger som ikke er basert på samtykke er et inngrep i personvernet, og det er derfor lagt strenge føringer for behandling av opplysninger fra Norsk pasientregister.

For at Norsk pasientregister skal kunne utlevere personidentifiserbare opplysninger må forskerne inn- 
hente de riktige godkjenningene for sitt prosjekt. For medisinsk og helsefaglig forskning gjelder dette forhåndsgodkjenning fra Regional komité for medisinsk forskningsetikk (REK), jf. NPR-forskriften $§ 3-6$ og helseforskningsloven $\S 33$ og $\S 9$. Til annen forskning kan det gis tilgang til personidentifiserbare opplysninger på grunnlag av konsesjon fra Datatilsynet jf. NPR-forskriften $\S 3-6$ og helseregisterloven $\S 5$. Dessuten må behandlingen være i samsvar med de alminnelige regler om taushetsplikt. Dersom det ikke er innhentet samtykke fra de involverte, må det dispenseres fra helsepersonells taushetsplikt og den forvaltningsmessige taushetsplikten. Dispensasjon fra taushetsplikten gis av henholdsvis REK, jf. helseforskningsloven $\S 35$ og helsepersonelloven $\S 29$ når formålet med bruken er forskning og av Helse- og omsorgsdepartementet når formålet med bruken er kvalitetssikring, administrasjon, styring og planlegging, jf, helsepersonelloven $\S 29$ b.

Selv om samtykke er hovedregelen både for innsamling og behandling av helseopplysninger, ser vi imidlertid at det svært sjelden er innhentet samtykke fra de involverte ved søknader om utlevering av personidentifiserbare opplysninger fra Norsk pasientregister. Manglende krav om samtykke grunngis vanligvis med at mange personer inngår $\mathrm{i}$ studiepopulasjonen, og at det derfor ikke vil være praktisk gjennomførbart å innhente samtykke fra den enkelte. Tilsvarende settes det ikke krav om informasjon til personer som inngår i studiepopulasjonen om at helseopplysningene deres blir brukt fordi mange mennesker inngår, jf. hovedregelen om informasjonsplikt i personopplysningsloven $\S 20$, 1. ledd.

Pasienter har ikke mulighet til å reservere seg mot registrering i Norsk pasientregister, eller mot at egne helseopplysninger blir utlevert fra Norsk pasientregister til forskningsprosjekter. I henhold til Norsk pasientregisterforskriften $\S 5-1$ har alle derimot rett til innsyn i egne helseopplysninger og i utleveringer som er gitt $i$ personidentifiserbar form. Norsk pasientregister er derfor forpliktet til å holde oversikt over alle utleveringer av personidentifiserbare data, slik at helseopplysninger og opplysninger om hvilke forskningsmiljøer som har fått tilgang til pasientens data kan hentes ut når registeret mottar innsynbegjæringer.

\section{DATA I REGISTERET ER PERSONIDENTIFI- SERBARE OGSÅ UTEN DIREKTE PERSON- IDENTIFISERBARE KJENNETEGN}

Anonyme helseopplysninger er opplysninger hvor navn, fødselsnummer og andre personentydige kjennetegn er fjernet slik at opplysninger ikke lengre kan knyttes til enkeltpersoner. Dette betyr at identifikasjon av enkeltpersoner ikke skal være mulig, verken direkte eller indirekte, jf. helseregisterloven $\S 2$ nr. 3. Følgende fremgår av Ot. prp. nr. 5 (1999-2000): "Det er ikke alltid at sletting av navn og fodselsnummer kan hindre identifisering av person. Det kan vare andre opplysninger, f.eks. utdannelse, yrke, bosted, alder, kjønn som kan identifisere person. Utgangspunktet er at dersom opplysningene kan knyttes til en av fire eller fem individer, er opplysningene anonyme." (6).

Denne definisjonen innebærer at data fra Norsk pasientregister er å regne som personidentifiserbare, selv når fødselsnummer er fjernet fra datasettet. Tilsvarende gjelder data fra før innføring av Norsk pasientregister som personidentifiserbart register. Vi vil i det følgende forsøke å forklare dette nærmere.

Norsk pasientregister inneholder informasjon om pasientens kjønn, fødselsår, bostedskommune, behandlende institusjon og ulike datoer (for eksempel dato for inn- og utskrivning og prosedyredato). Når det gjelder opphold for pasienter innlagt i somatisk sykehus, er det i $88 \%$ av tilfellene nok å ha opplysninger om behandlende institusjon og innleggelsesdato i tillegg til pasientens kjønn, alder og bostedskommune, for å kunne knytte oppholdet til én enkelt person. Med tilgang til innleggelsesmåned i stedet for eksakt innleggelsesdato kan $43 \%$ av innleggelsene knyttes til én enkeltperson. Slike opplysninger er lett tilgjengelige og oppholdsdata fra Norsk pasientregister oppfyller dermed på langt nær de kravene som stilles i definisjonen av anonyme opplysninger: de er bakveisidentifiserbare gjennom administrative opplysninger. Dette vil også ofte gjelde selv om alder er kategorisert og opplysninger om bosted på kommunenivå er fjernet.

For de aller fleste pasientene er det registrert flere opphold, noe som øker mulighetene til bakveisidentifisering ytterligere. For perioden før 2008 kunne gjenkjenning av ett opphold for en person gi opplysning om all behandling (tilstandskoder og prosedyrekoder) innenfor kalenderåret ved én institusjon for denne personen hvis datasettet inneholdt pasientnummeret. Siden data fra Norsk pasientregister fra 2008 er personentydige, er det nå slik at gjenkjenning av ett opphold gir tilgang til alle helseopplysninger som er registrert på pasienten, uavhengig av sektor, behandlende institusjon og kalenderår.

I eksemplene gjengitt ovenfor er det ikke tatt hensyn til noen medisinske opplysninger registrert på pasienten. Hvis man i tillegg inkluderer for eksempel hoveddiagnose, øker mulighet for bakveisidentifisering ytterligere.

Det viser seg derfor ofte at det er vanskelig å tilrettelegge anonyme datasett. Hvordan ulike variable kan grupperes og hvilke variable som kan slettes fra datagrunnlaget for å tilfredsstille kravene om anonymitet samtidig som resultatet er en analysefil som er nyttig for mottaker, avhenger av problemstillingene som skal belyses. Det lar seg derfor ikke gjøre å gi en generell beskrivelse av et anonymt datasett basert på Norsk pasientregister. Typisk vil erstatning av eksakte datoer med måned, tertial eller år, kategorisering av alder, eller fjerning av bosted på kommunenivå være muligheter som blir vurdert $\mathrm{i}$ anonymiseringsprosessen. Vi har imidlertid sett at datasett med løpenummer som knytter opphold for enkeltpersoner sammen er 
enda vanskeligere å tilrettelegge som anonyme enn datasett uten slikt løpenummer.

\section{EKSEMPLER PÅ STATISTIKK FRA NYE NORSK PASIENTREGISTER}

I det følgende gir vi eksempler på statistikk fra Norsk pasientregister etter etablering av personidentifiserbart register. Vi håper at disse eksemplene er illustrative og kan inspirere forskningsmiljøene til å vurdere bruk av statistikk fra Norsk pasientregister i forskningsprosjekter.

Enhet for registrering av data i Norsk pasientregister er opphold og tidligere publisert statistikk har vanligvis også hatt opphold som enhet. Tilgang til et personentydig løpenummer i Norsk pasientregister gir helt andre muligheter til å lage statistikk med person som enhet for analysene, spesielt for kroniske tilstander eller tilstander som krever behandling ved ulike institusjoner. Ved manglende innrapportering av fødselsnummer blir vanligvis et løpenummer basert på institusjons- og pasientnummer benyttet som erstatning, men god statistikk for antall pasienter er avhengig av høy kompletthet i innrapportering av fødselsnummer. Når gyldig fødselsnummer mangler kan ikke pasienter følges mellom behandlende institusjoner og pasienter behandlet ved flere institusjoner vil bidra til statistikken flere ganger, slik at totalantallet pasienter blir for høyt. Selv om komplettheten for alle opphold sett under ett er høy, er det viktig å vurdere komplettheten $\mathrm{i}$ hvert enkelt tilfelle, da det for enkelte pasientgrupper kan være lavere kompletthet, spesielt ved tilstander som ofte blir behandlet ved private sykehus.

\section{ANTALL PASIENTER I SPESIALISTHELSE- TJENESTEN I 2009}

I 2009 var over 1,8 millioner mennesker, eller nærmere $38 \%$ av befolkningen, registrert som pasienter ved somatiske sykehus, i psykisk helsevern og/eller som pasienter i tverrfaglig spesialisert behandling for rusmisbrukere (7). De aller fleste av disse hadde en eller flere polikliniske konsultasjoner ved somatisk sykehus (1,5 millioner mennesker, eller $31 \%$ av totalbefolkningen).

I aldersgruppen 7-17 år var 3,8\% av gutter og 3,6\% av jenter $\mathrm{i}$ totalbefolkningen registrert med minst ett døgnopphold ved somatisk sykehus i 2009. For gutter og jenter i samme aldersgruppe som var pasienter $\mathrm{i}$ psykisk helsevern for barn og unge, var disse andelene mye høyere: henholdsvis $6,5 \%$ og $10,1 \%$.

\section{Antall pasienter med appendektomi 2008-2009}

Data fra Norsk pasientregister er tidligere blitt benyttet til å undersøke forekomst av appendektomi og utvikling i bruken av laparoskopi for perioden 1990-2001 (8). Dette er en typisk problemstilling hvor det er unødvendig å benytte data med personentydig løpenummer: blindtarmen kan bare fjernes én gang. Det ble også gjort forsøk på å studere reinnleggelser, men resultatene måtte tolkes med forsiktighet da det ikke var mulig å få informasjon om eventuelle reinnleggelser ved andre institusjoner enn ved institusjonen hvor operasjonen ble gjennomført eller reinnleggelser som skjedde $\mathrm{i}$ et annet kalenderår.

$\mathrm{Vi}$ gjorde derfor tilsvarende analyser for perioden 2008-2009 ved først å velge ut alle opphold med prosedyrekode for appendektomi (9). Deretter ble utvalget avgrenset til alle opphold med hovedtilstandskode appendisitt 2008-2009. Vi undersøkte deretter reinnleggelser som øyeblikkelig hjelp innen 30 dager fra utskrivning fra opphold med kirurgisk prosedyre, og fant at omtrent $5 \%$ av pasientene hadde slik reinnleggelse. De aller fleste av reinnlagte pasienter (over $90 \%$ begge år) ble reinnlagt ved samme sykehus som hadde gjennomført appendektomien. For akkurat denne problemstillingen kan man derfor argumentere med at tilgang til personentydig løpenummer var unødvendig for å studere reinnleggelser etter primæroperasjon. Imidlertid, hvis vi ikke hadde hatt tilgang til personentydig løpenummer, hadde vi heller ikke hatt kunnskap om at appendektomerte pasienter sjelden blir reinnlagt på annet sykehus enn sykehus for primæroperasjon.

\section{Hovedtilstand hjerteinfarkt}

Som nevnt tidligere ble behovet for mer kunnskap om forekomst og behandlingsforløp ved hjertesykdom benyttet $\mathrm{i}$ argumentasjonen for å etablere Norsk pasientregister som et personidentifiserbart register. Vi har sett at $\mathrm{i}$ data for 2008 over somatiske innleggelser var antallet pasienter registrert med hovedtilstand hjerteinfarkt (ICD-10 kode I21.0-I21.9) basert på "Gamle NPR" i overkant av 17 500, men antallet pasienter basert på "Nye NPR" var i overkant av 12500 (9). Den store forskjellen $\mathrm{i}$ antall pasienter basert på institusjons- og pasientnummer og antall pasienter basert på personentydige data skyldes at en høy andel av pasientene (nærmere 40\%) var registrert ved mer enn én behandlende enhet med de aktuelle tilstandskodene.

\section{Pasienter registrert med "villet egenskade" ved somatiske sykehus}

I 2008-2009 ble over 3600 pasienter registrert med "villet egenskade" (ICD-10: X6n) ved somatiske sykehus (9). Ved å benytte oss av kryptert fødselsnummer for sammenkobling av data fra somatiske sykehus med data fra psykisk helsevern kunne vi undersøke om pasienter behandlet for villet egenskade i somatikk også var registrert som pasienter i psykisk helsevern. Vi fant at hele $85 \%$ av pasienter med villet egenskade var registrert med minst én kontakt i psykisk helsevern i løpet av 2008-2009. Selv om disse analysene er svært enkle, mener vi at disse funnene er viktige av to årsaker. For det første viser dette at pasienter registrert med villet egenskade ved somatiske psykehus får oppfølgning i psykisk helsevern. For det andre peker funnene $\mathrm{i}$ retning av at validiteten $\mathrm{i}$ denne kodingen for villet egenskade i somatiske sykehus er høy. Datama- 
terialet gir imidlertid ingen informasjon om eventuell underrapportering av villet egenskade ved somatiske sykehus.

\section{Personskadedata}

Med etablering av nye Norsk pasientregister skal spesialisthelsetjenesten og utvalgte kommunale legevakter rapportere personopplysninger (fødselsnummer) og opplysninger om kontaktårsak, skademekanisme, alvorlighetsgrad, aktivitet på skadetidspunktet, skadested, skadetidspunkt og arbeidsgivers bransje for alle personskadetilfeller som blir behandlet. I oppstartsperioden (1. mai 2009 - 30. april 2010, kun Oslo legevakt) ble det registrert over 50000 skadetilfeller (10). Kobling mot aktivitetsdata i Norsk pasientregister viste at de aller fleste skadene ble behandlet kun på poliklinisk nivå. Dataene viste markerte kjønns- og aldersforskjeller, med flest personskader registrert for unge menn og for eldre kvinner. Etter ulykkesskader fulgte voldsskader som viktigste kontaktårsak (henholdsvis $92 \%$ og $6 \%$ av det totale antallet personskader behandlet). Villede egenskader utgjorde omtrent $1 \%$ av skadetilfellene. Kobling mot aktivitetsdata i Norsk pasientregister viste at de mest brukte utskrivningsdiagnosene for sistnevnte pasientgruppe var relatert til åpne sår på underarm.

Siden datasettet også inneholder personopplysninger i form av fødselsnummer kan det sammenstilles med data fra andre registre, for eksempel for å belyse sammenhengen mellom sosioøkonomiske faktorer og ulykker som medfører personskade. Det er påpekt at dette er et område hvor det er behov for mer kunnskap (11).

\section{DATAKVALITET}

Kvaliteten på innrapporterte data fra primærkilden er avgjørende for Norsk pasientregisters evne til å videreformidle data av god kvalitet til brukerne. Dokumentasjon av datakvalitet og økt datakvalitet er derfor ledd i Norsk pasientregisters strategiarbeid. En ny strategiplan for økt datakvalitet er under utarbeidelse, med støtte fra Nasjonalt helseregisterprosjekt "Gode helseregistre - bedre helse" (12). I denne prosessen er det blant annet etablert en ekstern arbeidsgruppe med representanter fra bl.a. Kreftregisteret, Senter for klinisk dokumentasjon og evaluering (SKDE), Nasjonalt folkehelseinstitutt, Kompetansesenter for IT i helse- og sosialsektoren AS (KITH) og helseforetakene. Strategien er dermed forankret hos aktører som bidrar med data og/eller bruker data fra registeret.

\section{EKSEMPEL PÅ NY BRUK AV DATA FRA NORSK PASIENTREGISTER: NORSK PASIENTREGISTER SKAL LEVERE DATA TIL KREFTREGISTERET}

Kreftregisteret har siden 2002 innhentet pasientadministrative data fra sykehusene tertialvis for å kvalitetssikre at alle meldepliktige krefttilfeller blir rapportert.
Dette har foregått ved at Kreftregisteret har sendt spesifikasjon med utvalgte tilstandskoder til hvert enkelt sykehus. Data om opphold med aktuelle tilstandskoder er så blitt rapportert til Kreftregisteret.

De pasientadministrative dataene rapportert til Kreftregisteret representerer et utvalg av aktivitetsdata rapportert til Norsk pasientregister (dobbeltrapportering). Norsk pasientregister og Kreftregisteret har i 2010 derfor gjennomført et samarbeidsprosjekt med datasammenstilling. Komplettheten i fødselsnummer var høy for aktuelle opphold i til Norsk pasientregister $(99,1 \%)$, og Norsk pasientregister hadde informasjon om flere pasienter enn det som var tilfelle i de pasientadministrative dataene rapportert til Kreftregisteret. Basert på disse prosjektresultatene har Kreftregisteret besluttet at systemet med innhenting av pasientadministrative data fra sykehusene skal erstattes med innhenting av tilsvarende data fra Norsk pasientregister.

\section{TILGANG TIL DATA}

Data kan bestilles fra Norsk pasientregister i form av statistikk, anonymiserte data, avidentifiserte data eller personidentifiserbare data. Retningslinjer for tilgang til data finnes på våre nettsider. Søknad om tilgang til data skjer gjennom elektronisk søknadsskjema og registreres kontinuerlig i vårt saksbehandlingssystem. Juridisk vurdering av søknadene opp mot Norsk pasientregisterforskriften er sentralt og det blir gjennomført ukentlige fordelingsmøter hvor innkomne søknader blir gjennomgått.

Saksbehandlingstid for utlevering av statistikk og anonyme opplysninger skal være maksimalt 30 dager, mens utleveringer av personidentifiserbare data eller koblede opplysninger skal ha en saksbehandlingstid på maksimalt 60 dager, jf. Norsk pasientregisterforskriften $\S 3-8$. Det faktureres for medgått tid og ved større oppdrag gjøres det ofte et prisoverslag før igangsetting av oppdraget. På våre nettsider finnes veiledning til søknadsprosessen. For en effektiv behandling av søknaden, er det viktig at formålet med bruken av opplysningene er tydeliggjort og at det er spesifisert og grunngitt hvilke variabler som ønskes.

$\mathrm{Vi}$ vil anbefale forskningsmiljøene å vurdere om behovet for data i noen tilfeller kan dekkes gjennom at Norsk pasientregister tilrettelegger statistikk. Vi forstår forskningsmiljøenes behov for tilgang til personidentifiserbare data fra Norsk pasientregister. Vi mener imidlertid at det på grunn av personvernhensyn er viktig at det først gjøres en vurdering av om databehovet kan dekkes gjennom tilgang til statistikk som kan utarbeides i Norsk pasientregister. Det er et grunnleggende prinsipp i helseregisterloven at data skal utleveres på minst mulig personidentifiserbart nivå, og at all bruk av personidentifiserbare helseopplysninger skal begrunnes, jf. helseregisterloven $\S 11$. Bestilling av statistikk fremfor personidentifiserbare data vil også vanligvis være tids- og kostnadsbesparende, i og med at data kan utleveres som statistikk uten forhåndsgodkjenning, 
konsesjon fra Datatilsynet og fritak fra taushetsplikt.

Medarbeidere i Norsk pasientregister kjenner de ulike datasettene svært godt, og kan komme med forslag til hvordan de endelige tabellene kan se ut. Kostnadene forbundet med tilrettelegging av statistikk er etter vår mening vanligvis lave og saksbehandlingstiden er i mange tilfeller kortere enn de 30 dagene som er pålagt registeret gjennom forskrift. Selv om medarbeidere i Norsk pasientregister ofte bistår oppdragsgiver i utarbeidelse av en analyseplan, vil vi vanligvis ikke være involvert $i$ forskningen for øvrig og blir dermed ikke kvalifisert for medforfatterskap i henhold til Vancouverkonvensjonen. Det stilles imidlertid krav om at Norsk pasientregister nevnes som datakilde i publikasjoner (inkludert muntlige presentasjoner). Hvordan uttrekket som ligger til grunn for statistikken er gjennomført blir dokumentert gjennom vedtaksbrevet som følger utleveringen. Vårt mål er at dokumentasjonen skal ha en slik kvalitet at tabeller fra Norsk pasientregister skal kunne brukes i vitenskapelige publikasjoner. Ved datautleveringer ber vi om å bli holdt orientert om publikasjoner hvor data fra Norsk pasientregister inngår.

Det er viktig at den som vurderer bruk av data fra Norsk pasientregister er klar over skillet som går mel- lom det konsesjonsbaserte og det personidentifiserbare registeret. Det er ikke noe i veien for å få tilrettelagt statistikk basert på data fra perioden før innføring av personidentifiserbart register. Forutsatt at de nødvendige godkjenningene er på plass, kan Norsk pasientregister også levere ut data med indirekte personidentifiserbare (bakveisidentifiserbare) opplysninger fra det konsesjonsbaserte registeret. Det er imidlertid ikke tillatt verken for Norsk pasientregister eller for mottakere av datafiler å sammenstille opplysninger om pasientene for bakveisidentifisering. Data fra det konsesjonsbaserte registeret kan dermed heller ikke kobles mot andre datakilder.

\section{KONKLUSJON}

Personentydige data i Norsk pasientregister åpner opp for mange nye muligheter innen epidemiologisk forskning og vi oppfordrer forskningsmiljøene til å sette seg grundig inn i datainnhold og regelverk. Vi oppfordrer også forskningsmiljøene som ønsker tilgang til personidentifiserbare opplysninger til å kontakte Norsk pasientregister, gjerne allerede i prosjektplanleggingen, slik at eventuelle misforståelser kan avklares på et så tidlig tidspunkt som mulig.

\section{REFERANSER}

1. Forskrift om innsamling og behandling av helseopplysninger i Norsk pasientregister (Norsk pasientregisterforskriften). http://www.lovdata.no/for/sf/ho/ho-20071207-1389.html.

2. Bakken IJ, Nyland K, Halsteinli V, Huse UK, Skjeldestad FE. Norsk pasientregister: Administrativ database med mange forskningsmuligheter. Norsk Epidemiologi 2004; 14: 65-9.

3. Lov om helseregistre og behandling av helseopplysninger (helseregisterloven). http://www.lovdata.no/all/nl20010518-024.html.

4. Cappelen I. Etablering av personentydig Norsk pasientregister: utdrag fra høringsbrev og rapport. Norsk Epidemiologi 2004; 14: 71-7.

5. Ørstavik R i samarbeid med Cappelen I og Stoltenberg C. Helseregistre redder liv. Nasjonalt folkehelseinstitutt, 2005.

6. Ot.prp. nr. 5 (1999-2000) Om lov om helseregistre og behandling av helseopplysninger (helseregisterloven). http://www.regjeringen.no/nb/dep/hod/dok/regpubl/otprp/19992000/otprp-nr-5-1999-2000-.html?id=160165.

7. Antall pasienter i spesialisthelsetjenesten i 2009. http://www.helsedirektoratet.no/norsk_pasientregister/bruk_ av data/antall pasienter i spesialisthelsetjenesten i 2009 767384. Helsedirektoratet, 2010.

8. Bakken IJ, Skjeldestad FE, Mjåland O, Johnson E. Appendisitt og appendektomi i Norge 1990-2001. Tidsskr Nor Legeforen 2003; 123: 3185-8.

9. Nye NPR - fra opphold til pasient. http://www.helsedirektoratet.no/norsk_pasientregister/publikasjoner/nye_ npr_fra_opphold_til_pasient_730854. Helsedirektoratet, 2010.

10. Personskadedata i Norsk pasientregister. http://www.helsedirektoratet.no/vp/multimedia/archive/00306/IS1845_Personskade_306109a.pdf. Helsedirektoratet, 2010.

11. Alver K, Hesselberg Ø, Lyshol H. Sosioøkonomiske forskjeller i ulykkesskader. En oppsummering av nordisk litteratur. Rapport 2009:9, Nasjonalt folkehelseinstitutt.

12. Gode helseregistre - bedre helse. Strategi for modernisering og samordning av sentrale helseregistre og medisinske kvalitetsregistre 2010-2020. Utgitt 1272009 av Sekretariatet for Nasjonalt helseregisterprosjekt, Folkehelseinstituttet. Tilgjengelig på http://www.nhrp.no/. 